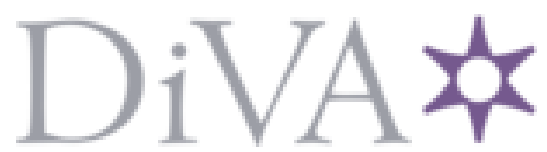

http://www.diva-portal.org

This is the published version of a chapter published in Women and credit in pre-industrial Europe.

Citation for the original published chapter:

Dermineur, E. (2018)

Credit, strategies, and female empowerment in early modern France

In: Elise M. Dermineur (ed.), Women and credit in pre-industrial Europe (pp.

253-280). Turnhout: Brepols

Early European research

https://doi.org/10.1484/M.EER-EB.5.115756

N.B. When citing this work, cite the original published chapter.

Permanent link to this version:

http://urn.kb.se/resolve?urn=urn:nbn:se:umu:diva-152507 


\title{
Credit, Strategies, AND FEMALE EMPOWERMENT IN EARLY MODERN FRANCE
}

\author{
Elise M. Dermineur ${ }^{1}$
}

'I do not wish them [women] to have power over men; but over themselves' - Mary Wollstonecraft, $A$ Vindication of the Rights of Woman

\section{Introduction}

In 2006, Muhammed Yunus and the Grameen Bank, a financial institution specializing in microcredit, won the Nobel Prize for peace 'for their efforts to create economic and social development from below. ${ }^{2}$ Many had believed that the development of microcredit institutions could contribute to the reduction of poverty, stimulate development, and empower women. By now, we know that the microcredit miracle did not occur and has not fulfilled its promise. ${ }^{3}$ But despite the

1 The author would like to acknowledge the generous financial support of Riksbankens Jubileumsfond.

2 'The Nobel Peace Prize 2006'. Nobelprize.org. Nobel Media AB 2014. Web. 8 May 2017. <http://www.nobelprize.org/nobel_prizes/peace/laureates/2006/>.

3 See for instance Duflo, Banerjee, Glennerster, and Kinnan, 'The Miracle of Microfinance?'.

Elise M. Dermineur is an associate professor of history at Umeå University and a Pro Futura Scientia Fellow at the Swedish Collegium for Advanced Study in Uppsala. Dermineur's publications include articles published in the Journal of Social History, The Journal of Interdisciplinary History, Traverse Revue d'Histoire - Zeitschrift für Geschichte, Social Science History, among others. In 2017, she published Gender and Politics in Eighteenth-Century Sweden, a political biography of the Swedish queen Lovisa Ulrika (1720-1782).

Women and Credit in Pre-Industrial Europe, ed. by Elise M. Dermineur, EER 12 (Turnhout: Brepols, 2018), pp. 253-280. 
critics, microcredit is still a widespread form of exchange in developing countries and even in developed regions worldwide. ${ }^{4}$

In pre-industrial Europe, microfinance was also widespread. Most pre-industrial European dwellers in search of capital turned to informal or semi-informal credit markets, lending and borrowing small or substantial amounts, either for their investments or to make ends meet. Before the advent of commercial and savings banks, finding funds occurred mostly at the local level through networks of acquaintances or brokered relations. In fact, most exchanges in pre-industrial Europe took place via credit. Debt and credit were, to a great extent, embedded in society.

Women's empowerment and credit activities are often considered part of the same package. This association has been increasingly reinforced thanks to the recent attention given to the microcredit revolution in developing countries. Today, most microfinance institutions give preference to female borrowers. About 95 per cent of the Grameen Bank's clients are women. ${ }^{5}$ Many believe that female access to loans engenders their subsequent empowerment. ${ }^{6}$ In pre-industrial Europe, on the other hand, this picture appears to be more nuanced. Chris Briggs has shown that in medieval England, for instance, credit networks brought little empowerment to women in traditional communities. This is because, he argues, too few women acted as independent lenders and borrowers. No significant impact ensued from their financial activities. ${ }^{7}$ Yet, as many contributions in this present volume show, it seems that the proportion of female borrowers and female moneylenders gradually increased across Europe from 1500 onwards, with more or less regularity and homogeneity. Here and there, historians have begun to report female credit endeavours; it has become clear that urban and rural women not only took part in credit activities but also that their activities were of significance. ${ }^{8}$ Across Europe, their marital status often determined their freedom of action in such markets.

4 Bhatt and Tang, 'Making Microcredit Work in the United States'.

5 Wahid, 'The Grameen Bank and Women in Bangladesh', p. 95.

6 Several economists support the positive correlation between credit activities - especially lending — and female empowerment. Recently, however, this assumption has been challenged. Ester Duflo and Abhijit Banerjee, for instance, have shown that, despite the fact that most micro-borrowers are women, they do not seem to enjoy any form of empowerment. The two economists explain this is because these women do not use the capital borrowed to invest in profitable activities but, rather, to overcome difficulties. Banerjee and Duflo. Poor Economics, p. 171.

7 Briggs, 'Empowered or Marginalized?'.

${ }^{8}$ See for instance Hanawalt, The Ties That Bound, p. 151. Jordan, Women and Credit. Laurence and others, eds, Women and their Money. Lemire and others, eds, Women and Credit. 
The recent investigations made by scholars have therefore revealed that women were active in these premodern credit networks. This has encouraged historians such as William C. Jordan, for example, to question the social importance of credit networks with high female participation. ${ }^{9}$ Building upon this analysis, this article is concerned with the impact of credit activities on women's lives. What did their involvement mean for the community and for their household? Was credit a factor in female emancipation and empowerment? In attempting to answer these questions, I examine the role of women in rural and local credit markets in eighteenth-century France. The emphasis is placed particularly on their role as creditors and debtors, but also, and above all, on the social consequences of their involvement in such transactions. Through the examination of about 2000 loan contracts (1730-1790) from two rural manors located in the south of Alsace - the seigneurie of Delle and Florimont - it is possible to reconstruct women's socioeconomic networks and show that their position both as lenders and borrowers was far from negligible, thereby supplying some answers to the many questions that remain regarding women and credit. As 'there is something distinctive and significant about women's roles in credit', their contribution was critical. ${ }^{10}$ To appreciate the role played by women in financial exchange, it is essential first to review their actions within the framework of the local credit market, secondly as debtors, then as creditors, with special reference to their marital status, and finally to question their social empowerment. Crossing the results of our investigation regarding notarial loan contracts with other sources allows us to sketch some features of the early modern empowerment framework.

\section{Female Borrowers and Female Lenders in Eighteenth-Century France}

\section{Local Credit Markets}

In early modern France, as in other European regions, various circuits of credit coexisted. ${ }^{11}$ Urban and rural dwellers could invest their savings or locate available funds either through informal circuits or through the institutional credit market. Informal credit activities were mostly private agreements contracted between a lender and a borrower, with no institutional intercession. These transactions were often oral, sometimes registered privately in writing in a livre de raison, or on a

\footnotetext{
9 Jordan, 'Women and Credit in the Middle Ages'.

${ }^{10}$ Jordan, Women and Credit, p. 1.

11 On this see especially Hoffman and others, Priceless Markets.
} 
loose piece of paper. Most of these small exchanges elude us; they do not appear in the archives except in probate inventories, which give an incomplete picture, at a given time, of an individual's credit standing, i.e. at his death. ${ }^{12}$ On the other hand, historians have been able to gather more information regarding the institutional credit market. Creditors and borrowers could agree on a loan and register their transaction through the intercession of a notary. These notarial registers constitute the backbone of my investigation.

I have compiled and examined notarial registers for two rural Alsatian manors. ${ }^{13}$ From 1730 to 1790 , the registers of the seigneurie of Delle and the seigneurie of Florimont are continuous and offer vital information regarding local credit activities and credit networks. The sample covers a total of 2085 notarial deeds. In the seigneurie of Delle, the registers contain a total of 1463 loans, while in the seigneurie of Florimont, the registers account for 622 contracts (see Table 10.1). The volume exchanged in both seigneuries throughout the period did not reach a high ceiling compared to larger towns. In Paris, for instance, in the eighteenth century, millions of livres were exchanged on an annual basis. ${ }^{14}$ But our sample is nonetheless consistent with other rural areas in terms of volume exchanged. ${ }^{15}$

Table 10.1. General overview of the credit market in the seigneuries of Delle and Florimont $1730-1790$ (in livres).

\begin{tabular}{lcc}
\hline & Seigneurie of Delle & Seigneurie of Florimont \\
\hline Number of contracts & 1463 & 622 \\
\hline Volume & 442,573 & 304,534 \\
\hline Average loan & 302.5 & 489.6 \\
\hline Median loan & 200 & 200 \\
\hline
\end{tabular}

In both seigneurie, obligations contracts were largely preferred over any kind of annuity at the notary's office. Registering a loan transaction with the notary against a fee - allowed both parties to secure their transaction, especially in the

12 On this issue, see notably Lindgren, 'The Modernization of Swedish Credit Markets'.

13 I have used the notarial registers of the seigneurie of Delle and the seigneurie of Florimont at the Archives Départementales du Territoire de Belfort (ADTB hereafter); 2E 4/155-159, 2E 4/194, 2E 4/222-223, 2E 4/245-246, 2E 4/257-258, 2E4/279-280.

${ }^{14}$ Hoffman and others 'Redistribution and Long-Term Private Debt'. See especially the graph on page 260 .

15 Nuits-Saint-Georges's volume of exchange can be compared to the seigneurie of Delle and Florimont for instance. See Rosenthal, 'Rural Credit Markets and Aggregate Shocks', p. 292. 
context of uncertainty about the repayment capacity of peasants. Increasingly, throughout the eighteenth century, official authorities such as the notary represented indisputable guarantors and intermediaries, and peasants gradually resorted to their services more and more often. The deed itself followed specific legal norms and gradually standardized the transactions. The contract traditionally contained the following information: the date, the names of both parties, their marital status, their place of residence, sometimes their professions and their kinship relations if any; the amount lent and received, and the interest fee ( 5 per cent was the common legal norm and cap in early modern France); the duration of the loan; the guarantees and mortgages promised, and often the name of one or several guarantors. ${ }^{16}$

Participation in the local credit market was theoretically open to everyone with available savings to invest or anyone who sought credit, provided that they had enough social and economic capital to back the loan. Women could participate legally in these financial exchanges. Their marital status, however - especially for married women - limited their freedom of action. Female minors could borrow and lend money with the legal assistance of their father or a male guardian. Unmarried women over twenty-five years-old - the age of majority - could also engage their assets and seek capital with the assistance of a male relative or a guardian. However, it appears that this rule was not always consistently enforced. Most of these unmarried women, who had reached their majority, appeared at the notary's office on their own. Married women could not legally borrow or extend money without their husbands' permission. But equally a husband could not engage his wife's assets without her consent. Married couples had to agree on financial transactions, since a loan involved their responsibility as borrowers and their mutual assets as creditors. Finally, a widow could legally manage her assets as she wished. Her legal capacity resembled those of men; Scarlett Beauvalet Boutourye pinpoints this phenomenon as the widow's 'retrieved legal capacity'. ${ }^{17}$

\section{Women as Borrowers}

Philip Hoffman and his co-authors note that if influential women could readily lend, it is true that they still had difficulty borrowing. ${ }^{18}$ In general, throughout early modern France, women had a narrower access than men to resources that

16 Lending money was a risky activity and guarantees were almost always sought to secure the transaction. Debtors pledged their land, livestock, upcoming harvests, houses and dependent buildings and so on. A third party underwriter could be added to the deal.

17 Beauvalet-Boutouyrie, Etre Veuve.

18 Hoffman and others, 'Information and Economic History', p. 91. 
included financial markets, labour opportunities, inheritance, and legal rights. Regional distinctions and legal norms could accent this discrepancy further. Without adequate assets, guarantees and social capital, women had difficulty in locating available funds and securing transactions. In the seigneurie of Delle, however, women (regardless of their marital status) signed 684 loans ( 46.75 per cent) and borrowed a total of 226,655 livres ( 51.2 per cent of the total exchanged), while in the seigneurie of Florimont, female borrowers signed 353 deeds ( 56.7 per cent of the total) for 128,055 livres borrowed ( 42 per cent of the total). In other words, women, in both seigneuries, borrowed almost half of the capital available. But if we consider these figures more closely, it appears that marital status played a key role in the allocation of funds (see Table 10.2). Unmarried women and widows represented the minority of borrowers, while the proportion of married couples in need of credit increased throughout the century to reach a significant proportion in the final decade. ${ }^{19}$ Very little information was provided regarding the purpose of the loan. Some transactions were in real money, delivered in cash, while other were delayed payment agreement.

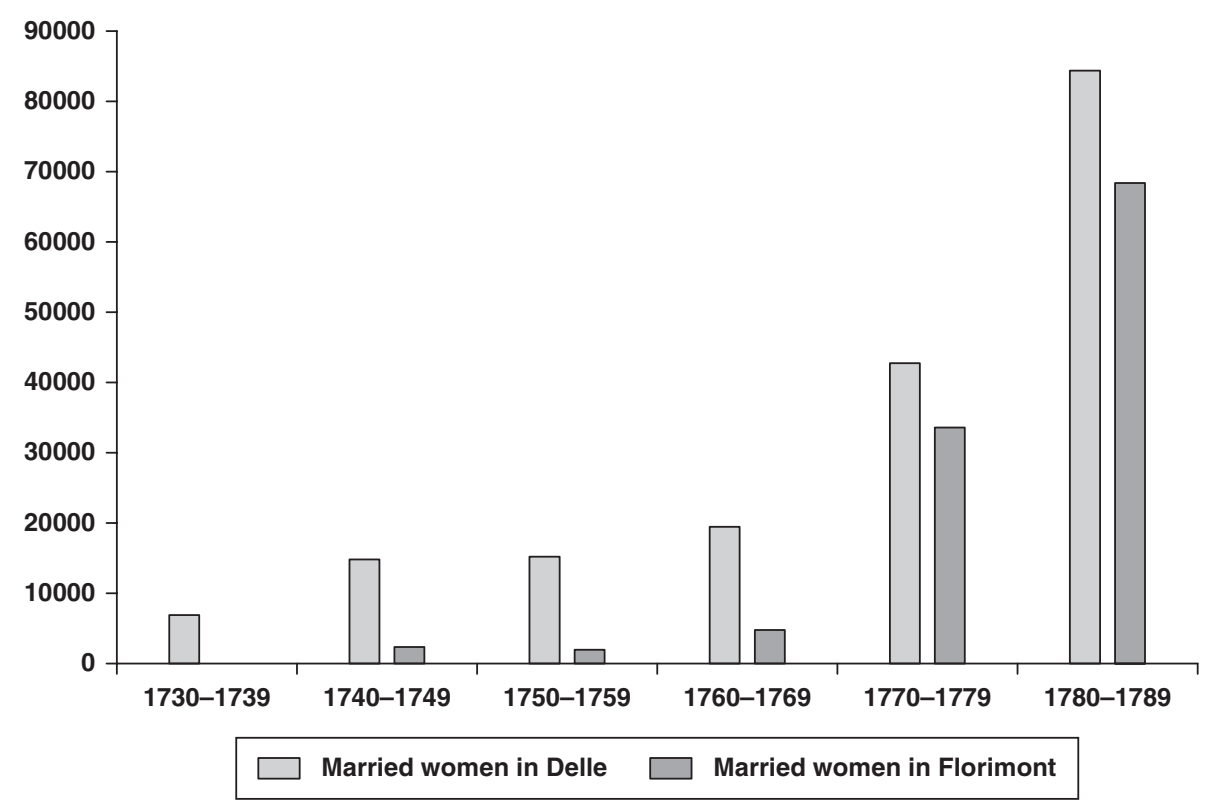

Figure 10.1. Married Women as debtors in the Seigneurie of Delle and Florimont, 17301790 (Volume of Exchange).

19 Unmarried women or single women, in this article, refers to a group of women who are over twenty-five years old and unmarried. Their status might have been transitory - they would eventually marry — or permanent. 


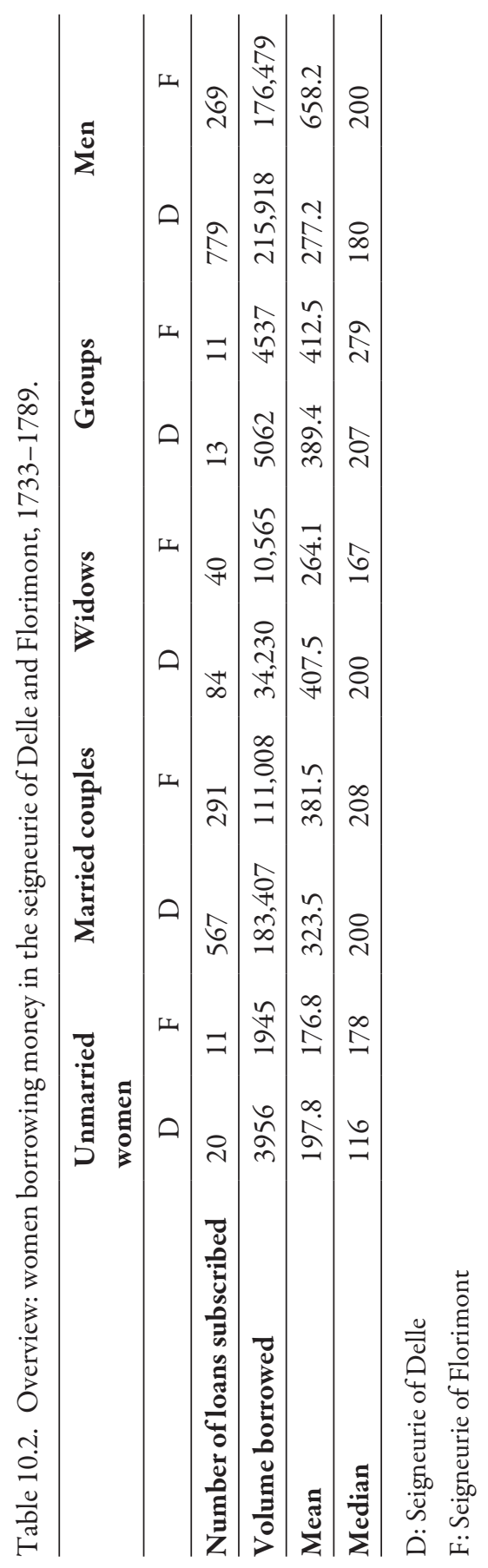


In the period we note the increasing share of married couples in the volume of exchange, with a rapid increase starting in the 1760s and continuing onwards (see Figure 10.1). How can we explain that, quite suddenly, male debtors included their wives in these deeds? Not only did married couples seek more funds but there were also gradually more of them doing so in the credit market. This phenomenon could be observed in both seigneuries and the shift seemed to have occurred at the same time. In Delle, 567 married couples sought credit ( 38.75 per cent) for a total of 183,407 livres ( 41.44 per cent) throughout the period. While they represented only 29.04 per cent of the borrowers in the 1730s, this became 47.41 per cent in the last decade of the Ancien Régime. In the seigneurie of Florimont, the same pattern applied. 291 married couples ( 46.78 per cent) signed loans at the notary for a total volume of 111,008 livres (36.45 per cent), their proportion increasing in number throughout the eighteenth century; while only 15.6 per cent in the first period of our sample, this became 47.4 per cent in the last decade. In both seigneuries, the increase of married debtors was constant, but seems to have taken off in the late 1760s as Figure 10.1 shows.

Contextual conditions, and factors such as rampant inflation, high demographic pressure, fragmentation of land, etc., undoubtedly pushed more and more people to locate available funds in the credit market. Indeed, if we look at the figures closely, the volume of exchange increased rapidly in the last two decades of the Ancien Régime. As already stated, the notarial documents rarely specify the purpose of a loan. It is extremely difficult for us to uncover what purpose a loan served. But how and why did married couples become the main debtors in the second half of the eighteenth century? Why did this particular group of debtors come to monopolize almost half of the capital available in the credit market? There are several possible explanations for this phenomenon.

First, peasants gradually placed more trust in the person of the notary to secure their transactions; as repayment could be sought in court, it was essential to keep track of financial transactions with official documents. This new confidence in the figures of authority may partially explain the increasing number of people who signed a deed at the notary's office (see Table 10.1), but this still does not explain why it was specifically married couples who abruptly became the main borrowers after the 1760 s. $^{20}$

The central explanation may lie in the fact that peasants had increasingly mortgaged a good deal of their land in order to secure their transactions, possibly in the seventeenth and at the beginning of the eighteenth century. ${ }^{21}$ Some pieces of

${ }^{20}$ More on this phenomenon in Dermineur, 'Trust, Norms of Cooperation, and the Rural Credit Market'.

21 Dermineur, 'Female Peasants, Patriarchy, and the Credit Market'. 
land had been mortgaged for considerable periods of time. Creditors had no control over, and no information on, what land had been mortgaged or not, since no method of tracking this had been established - even if the intercession of notaries could be helpful to inform them in this matter. In the meantime, the numbers of default proceedings at court dramatically increased after $1760 \mathrm{~s} .{ }^{22}$ In this context of lack of information and trust deficit, creditors were eager to secure their investments through new guarantees.

In the 1730s and 1740s, most of the loans contained specific mortgage guarantees, usually a specific plot of land, while at the end of the period the notary laconically inscribed on most contracts that the debtor(s) would mortgage 'tout ses biens tant meubles qu'immeubles. ${ }^{23}$ Third party underwriters were gradually added to the deed, while it is possible women's lineage property - especially their dowries - became even more interesting to creditors. Indeed, as we have already noted, there was a dramatic increase in the number of married women who were involved in loan deeds after the late 1760s. Husbands and wives borrowed together and therefore offered greater guarantees to their creditors. Mortgaged lands no longer seemed to represent enough of a guarantee, and married women's property (mostly un-mortgaged plots of land and cash either inherited or owned through dowries) now seemed to represent an additional and greater guarantee in the eyes of creditors. Finally, creditors could legally seek repayment by turning to the widow for her share of the debt in the case of her husband's death..$^{24}$ After 1760 , peasants not only had to add their wives and their wives' lineage property to the deed, but also had to find, in most cases, a third-party underwriter to reassure lenders.

We might legitimately ask whether married women were forced to sign loans alongside their husbands. Considering the traditional and patriarchal characteristics of rural societies, this question appears to be justified. A few examples can help us to better understand the extent of household partnerships. In April 1770, André Duprez and his wife borrowed 200 livres from the local judge in order for the couple to buy two new bulls for their farm. In January 1778, Pierre Joseph Rouge, a retired cavalryman, consented to extend credit to a couple of peasants, Ignace le

22 On this point, see especially Dermineur, 'Trust, Norms of Cooperation, and the Rural Credit Market.'

23 'All his movable and immovable goods'.

${ }^{24}$ In the case of a husband borrowing money on his own, the repayment passed to his heirs upon his death. His wife, then, was responsible for a third of the debt but could refuse the inheritance and let down the creditor(s). His children were responsible for the other two-thirds. But in the case that a husband and wife signed a loan together, she was responsible for half of it and had to reimburse the creditor(s). See Dermineur. 'Widows' Political Strategies'. 
Jeune and his wife Marie Catherine Surlet, in order for them to build a new house. In August 1780, Jean Baptiste Girardin and his wife Sophie Erard bought, with deferred payment, several items for their inn from a merchant. These three examples illustrate the partnership that existed between husband and wife within their households. As peasant households have always had to turn to creditors to pay their taxes, buy new lands or just for subsistence purposes, credit was most definitely an integral part of the household's experience. The partnership existing between spouses represented in fact a form of survival strategy, in which the household prevailed over the individual.

Women had always contributed to the household income in one way or in another. Signing an official deed at the notary held them responsible for half of the debt. Some historians have underlined the fact that, given their property was at stake, signing was an indication of submission. Instead, I think that women turned to become critical business partners at this point. The fact that women's lineage property and assets were at stake did not represent a reinforcement of patriarchy, but rather a breach of it, as women retained the right not only not to sign the deed if they did not want to, but were also able to withdraw their assets, by requesting a legal separation of property before the judge, if they considered that the financial situation of their household was endangered by their husband's decisions. ${ }^{25}$ This is a key moment, therefore, when the erosion of patriarchy as a societal model began. Men were no longer in command of their households. Their guarantors possessed external control over the household's husbandry of resources, and their wives had to play a more critical role in the household management. From this point on, economic partnerships between spouses became even stronger and could be regarded as a survival strategy to cope with indebtedness. I believe this is a form of empowerment; women gaining more weight in their role of household partner. New economic conditions, such as those described in this here, made married women an important household component and associate. I will return to this point.

If women had access to the credit market as borrowers, they also played a key role in the extension of credit as lenders. Marital status, once again, remains a key tool of analysis.

\section{Women as Creditors}

In a common assumption, financial transactions in early modern Europe were traditionally associated with the manly sphere of business and trade, and almost

25 On this topic see especially Hardwick, 'Seeking Separations'. 
automatically excluded women. Supposedly, women were less well connected than men, had no legal access to public positions, and had less incentive and opportunity regarding commercial transactions, which in turn diminished their chances of meeting potential business partners. Historians have nonetheless found evidence that women were involved in credit markets, as this volume demonstrates.

If we know little about the role of female creditors, we know even less about the involvement of women in rural credit markets. The monetization of exchange entered slowly into the mechanisms of the local economy in the early modern period. Women's access to capital was more complicated than in urban areas, because of the specificities of household and labour structures that were more commonly shared and mutualized. In rural areas, the household prevailed over the individual, especially in regards to the management of resources and consumption strategies. Men, as heads of their families, thus tend to appear more in the sources. Nonetheless, in the seigneurie of Delle, female investors, regardless of their marital status, signed 278 contracts ( 19 per cent of the total contracts) for a volume of 83,453 livres (18.8 per cent of the total exchanged), while in the seigneurie of Florimont female investors appeared in 136 deeds ( 21.9 per cent) for a volume of 81,035 livres (26.6 per cent).

In order to examine the female contribution to the credit market, we are bound to divide women into categories according to their marital status. Marital status, indeed, not only determined the credit capacity of women but also determined their social position within the community; it is therefore a key tool of analysis.

Unmarried women and widows represented the majority of the women who extended credit in both seigneuries. Intriguingly, unmarried women ranked first among female creditors. ${ }^{26}$ In the seigneurie of Delle, 152 contracts were signed by unmarried women out of a total of 1463 contracts ( 10.4 per cent) for a total amount of 32,948 livres out of 442,573 livres in total (7.44 per cent). Similar figures are found in the seigneurie of Florimont, where unmarried women signed 59 contracts ( 9.48 per cent) for a total of 31,062 livres (10.2 per cent). In the seigneurie of Delle, 78 contracts were signed by widows ( 5.3 per cent) for a total amount of 32,628 livres (7.37 per cent). In the seigneurie of Florimont, widows signed 44 contracts (7.07 per cent) for a total amount of 25,125 (8.25 per cent). The proportion of married women as moneylenders was quite low in both seigneuries. The capital they extended reached 4 per cent of the total volume in Delle and 7.36 per cent in Delle. For the purpose of this article, the focus is especially on unmarried women and widows.

26 Amy Froide states that in Southampton single women loaned out more money than widows. Froide, Never Married, p. 133. 


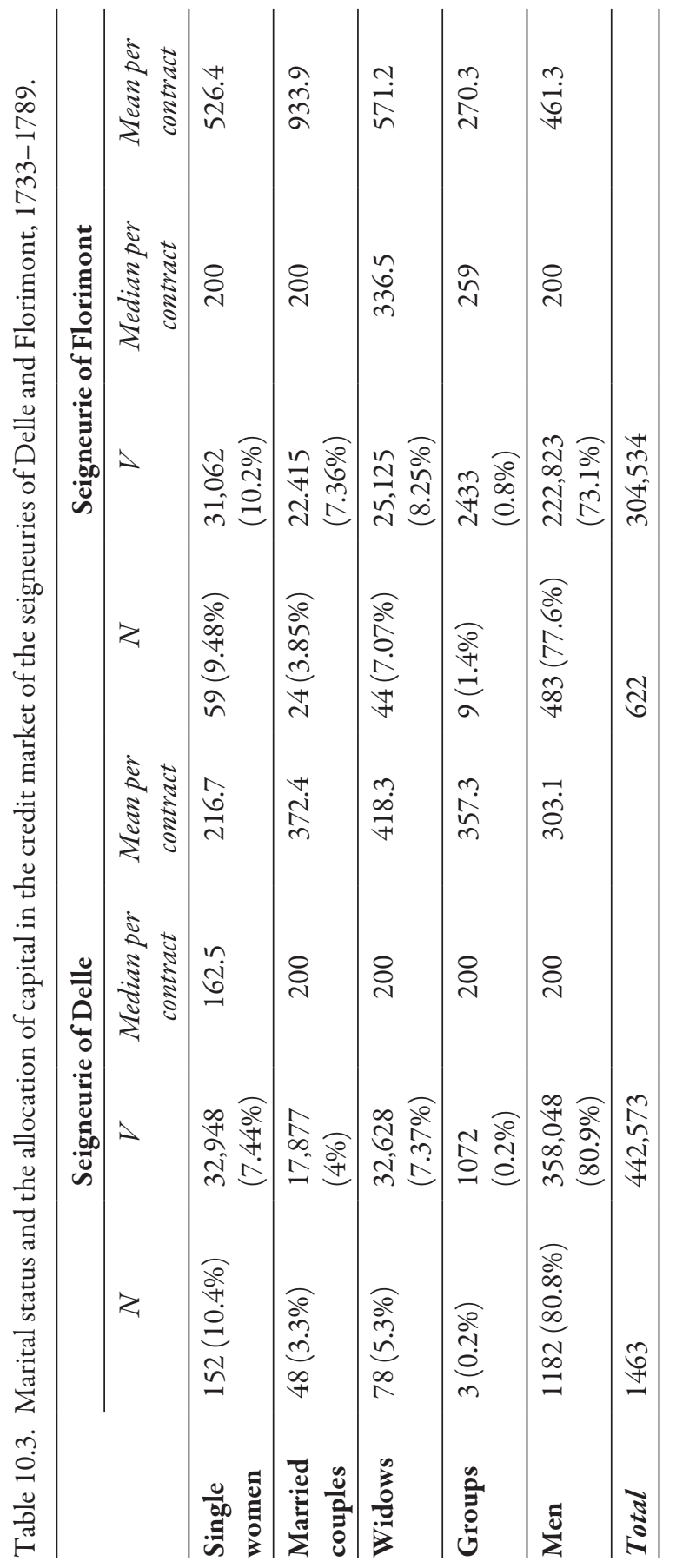


Entering into the credit market as a creditor supposes sufficient financial means. In traditional societies, we might ask where the money came from that these women possessed. Where did they find the necessary resources to have surplus to invest and lend? Answering this question will help us in turn to determine if whether or not women were empowered by moneylending.

\section{Unmarried Women}

Marguerite Duprez was a domestic in the town of Delle. ${ }^{27}$ She had emigrated there from her native village of Saint-Dizier-l'Evêque, located only a few kilometres away. In 1777, still unmarried, she loaned money to Joseph Tallon (120 Livres) and in 1784 to Pierre Michelat and his wife (220 livres), both from Saint-Dizierl'Evêque. ${ }^{28}$ She thus kept an existing bond with her native community. Incidentally, she continued lending money there after she married. In 1788, Marguerite Duprez and her husband, lent 255 livres to Madelaine Michelat, also from the same village.

Like Marguerite Duprez, many single women invested their wages as rural domestics in the local credit market. Sheilagh Ogilvie estimates that 'between the ages of 25 and 45, about one quarter of unmarried women still lived as servants'. ${ }^{29}$ In the seigneurie of Delle and Florimont, young men and women often worked as domestics in wealthy farms or shops before establishing a household of their own. If a few young men worked as apprentices in artisan shops in villages and neighbouring towns, some young women could find employment as qualified workers in market-based sectors, especially in textile production. These qualified workers, however, often had to emigrate to larger towns. This did not prevent them maintaining strong ties with their native village, as our example shows. As Laurence Fontaine puts it, female servants were at the heart of a system of capital redistribution. ${ }^{30}$ The capital amassed by these female domestics could not be kept safely at home; it was

27 On this, see especially Dermineur, 'Single Women'. When we refer to early modern single women, we target the group of women to have reached reproductive age, who were able to work, who remained single for some time - this period could be more or less long depending on several factors - or who never been married at all. All these women had in common the fact they had lived without the authority and social protection of a husband.

28 ADTB 2E4/279 and 280.

29 Ogilvie, A Bitter Living, p. 271.

${ }^{30}$ Fontaine, Pauvreté, Crédit et confiance dans l'Europe préindustrielle, p. 156. 
undoubtedly more secure invested in the credit market. I have found evidence that male domestics also invested their wages in the credit market.

Another source of capital for unmarried women was constituted in property and money they might inherit. Judith Spicksley shows that this revenue motivated most of the single women involved in lending activities in her British sample in the seventeenth century. ${ }^{31}$ The seigneuries of Delle and Florimont were both located in a region where partible inheritance was the norm. The parental patrimony was shared equally among the heirs - the children — regardless of gender. This legal norm, therefore, contributed greatly to the independence of women, and certainly benefitted unmarried women deprived of an income or family assistance since they could use their share in case of necessity. It is difficult, however, to estimate precisely in which cases and on what occasions single women chose to invest their inherited capital in the credit market.

We might therefore wonder whether single women with regular incomes, such as domestics and rural workers, and/or with inheritance possibilities, were constrained to extend credit to their relatives. Because they lacked the support of a spouse and were in a vulnerable position - presumably more so than other community members - were single women constrained to extend credit to their relatives? Were they in a position to resist such demands? We certainly do lack points of comparison to answer this complex question. In Paris, Hoffman found that only 3 per cent of the borrowers and creditors were blood related. In rural areas, this percentage was higher, given the stronger norms of cooperation, solidarity, and endogamy. In England, Holderness found that 40 per cent of lenders and borrowers were blood related, while Wrightson and Levine counted 17 per cent of loans contracted by family members in a British village. ${ }^{32}$ In the seigneurie of Delle, 7.4 per cent of all transactions were between members of the same family, while this rate reached 8 per cent in Florimont. In both seigneuries, women, regardless of their marital status, were more likely to extend credit to their relatives than did men, but they lent small amounts of money in comparison with the overall median. In Delle, 10.6 per cent of single women extended credit to their relatives, while 23.7 per cent did so in Florimont - but in this seigneurie, they were also less numerous, which in turn biases the significance of this percentage. As a point of comparison, Spicksley found that a third of single women lenders provided credit for family and kin. ${ }^{33}$

31 Spicksley, “"Fly with a Duck in thy Mouth”', p. 198.

32 Holderness, 'Widows in Pre-Industrial Society', p. 441. Wrightson and others, Poverty and Piety, p. 100.

33 Spicksley, “"Fly with a Duck in thy Mouth”, p. 198. 
While these figures were slightly higher than average, nothing indicates that family members took advantage of the incomes of single women, especially when we compare them to other groups (see Table 10.4 below).

Compared to male creditors, single women did extend credit more often to their relatives. This can be explained by the fact that, unlike men, they lacked commercial connections and public visibility. They lent money to people in their direct circle of interaction without necessarily being constrained to do so. The fact that unmarried women took the precaution to register their transactions before the notary reinforced the argument that a loan to a family member had to be repaid. It would be valuable to compare these results with informal transactions. ${ }^{34}$

Table 10.4. Same family contracts in the seigneuries of Delle and Florimont, 1730-1790.

\begin{tabular}{llccccc}
\hline & \multicolumn{2}{c}{ Same family contracts } & \multicolumn{2}{c}{ Volume } & \multicolumn{2}{c}{ Median } \\
\cline { 2 - 7 } & \multicolumn{1}{c}{$D$} & $F$ & $D$ & $F$ & $D$ & $F$ \\
\hline $\begin{array}{l}\text { Single } \\
\text { women }\end{array}$ & $16 / 152(10.5 \%)$ & $14 / 59(23.7 \%)$ & 4,106 & 4,946 & 151 & 195 \\
\hline $\begin{array}{l}\text { Married } \\
\text { couples }\end{array}$ & $11 / 48(22.9 \%)$ & $2 / 24(8.3 \%)$ & 6,154 & 236 & 150 & 118 \\
\hline Widows & $3 / 78(3.8 \%)$ & $5 / 44(11.3 \%)$ & 545 & 1,531 & 200 & 240 \\
\hline Groups & $1 / 3(33.3 \%)$ & $2 / 9(22.2 \%)$ & 672 & 735 & 672 & 368 \\
\hline Men & $77 / 1181(6.51 \%)$ & $27 / 483(5.6 \%)$ & 25,578 & 10,608 & 179 & 288 \\
\hline Total & $108 / 1463(7.4 \%)$ & $50 / 622(8 \%)$ & 37,055 & 18,057 & 174.5 & 249.5 \\
\hline
\end{tabular}

When we closely examine the network of debtors of single women, it appears that these women chose to extend capital principally to men ( 48.7 per cent in Delle, 44 per cent in Florimont) and married couples (respectively 39.5 per cent and 35 per cent), denoting a safe strategy on their part. Indeed, in the case of married couple debtors, both spouses guaranteed the loan. If one of the borrowers died, the other was still accountable for that share of the debt along with the heirs, increasing the safety of the capital investment. Men were also sought-after borrowers as they could easily bring collateral and mortgages to secure the transactions. Amy Froide has highlighted the same lending strategy on the part of single women in

${ }^{34}$ Informal transactions were private agreements contracted outside the notary's office. These exchanges can be tracked thanks to probate inventories. 
Bristol. There, women also overwhelmingly extended capital to men (ten out of twelve loans). ${ }^{35}$ Despite the strong norms of solidarity and cooperation in traditional communities, it seems that single women were also careful investors.

Single women, indeed, protected their capital and did not lend blindly. On 9 September 1743, Marie Agathe Maraget lent 60 livres in cash to her neighbour Nicolas Charbonnier. She secured her transaction by asking Charbonnier for a specific piece of land to be mortgaged (an orchard in this case), and she also required a guarantor. ${ }^{36}$ On March 1745, Jeanne Preney extended money to one of her relatives, Maurise Preney, and her husband Jean Pierre Bernard. She delivered to them the amount of 100 livres in cash. The money presumably came from her wages; she was employed by the village priest as a domestic. In order to secure the transaction, and perhaps because she feared she would not retrieve her capital for some reason, she asked for the mortgage of a meadow and a piece of arable land. ${ }^{37}$ Many examples such as these ones can be found. Most single women tightly secured their transactions and diversified their portfolios.

\section{Widows}

Anne Marie Monnier was married to the laboureur Nicolas Jeantine. Perhaps because her husband was overwhelmed with farm tasks, or perhaps because she was extending credit on her own money, she, alone, was present before the notary on November 1771 and on June 1777. On the first occasion, she extended credit for a total of 500 livres to Pierre Jacquet and Marie Anne Liron, a married couple living in her village of Suarce. ${ }^{38} \mathrm{~A}$ few years later, in 1777 , she agreed to renew an old obligation and to extend a new loan to Catherine Frin, the widow of Henri Werther, in order to rebuild her house destroyed by a fire. Anne Marie Monnier lent Catherine Frin 880 livres. ${ }^{39}$ She delivered the money to her clients, and her husband countersigned the deeds later; but on this occasion too, he left her to go alone to the notary.

When Monnier's husband passed away in 1779, at fifty years old, she did not remarry and managed her property in her own name as head of her household. ${ }^{40}$ She continued to extend credit to her neighbours and friends. But in 1783,

35 Froide, Never Married, p. 135.

36 ADTB 2E4/157.

37 ADTB 2E4/157.

38 ADTB 2E4/443 15 novembre 1771.

39 ADTB 2E4/444 13 juin 1777.

40 ADTB Registre paroissial 095 E dépôt GG 1-5. 
perhaps feeling she could not work any longer, she invested a considerable amount of money in the credit market, presumably in order to secure a regular income for her retirement. Like her, widows were often eager to invest in the credit market to secure a fixed income, especially if they had no offspring. ${ }^{41}$ She extended a total of 3173 livres to ten different borrowers, all living in her village, thus spreading risk. ${ }^{42}$ Most of the capital repayment deadlines were on demand, indicating her willingness to receive fixed amounts of money from the interest every year. The transactions were all risk-limited as all the borrowers lived in her village, most of them were married (if one spouse died, the other was still responsible for his or her share of the debt), the repayment date was on demand, meaning she could withdraw her capital anytime (with notice) if needed, and she diversified her investment in lending her capital to ten different debtors, thus spreading the risk. Most of the widows extending credit sought an annual return worth their investments; especially aging widows who attempted to diversify their income.

In practice, a widow regained full legal capacity but in theory her access to labour, resources, lands, and money remained extremely difficult. ${ }^{43}$ Julie Hardwick states that 'widows often found it difficult in daily practice to take advantage of the autonomy their legal position promised'. ${ }^{44}$ But some widows, the wealthiest among them, however, had enough resources to invest in the credit market, like Anne Marie Monnier. Most of these women inherited part of the community property assets and/or had funds of their own. For instance, widows got back their dowries and could also have inherited from their parents - partible inheritance was the rule there. This has prompted scholars to recognize the centrally important role of widows in local economies, at the heart of the redistribution system for its active members. ${ }^{45}$

Many widows did extend money in the credit market in order to secure their old age. ${ }^{46}$ This strategy was quite common in urban areas for wealthy widows. ${ }^{47}$ In

41 In Württemberg, widows also invested in state mortgages. See Sabean, Property, Production, and Family, p. 47. Laurence Fontaine has noted the same thing among early modern French widows. Fontaine, $L$ 'économie morale, p. 157.

42 ADTB 2 $4 / 445$.

43 Scarlett Beauvalet-Boutourye is quite positive about the status of widows in this era and talks about 'la capacité retrouvée'; Beauvalet-Boutourye, Etre Veuve, p. 195.

${ }^{44}$ Hardwick, 'Widowhood', p. 133.

45 Jordan, 'Women and Credit in the Middle Ages', p. 47.

46 See also Rosenhaft, 'Did Women Invent Life Insurance?'.

47 See Zuijderduijn's article in this volume for more details on female investors and life insurance. 
the seigneurie of Delle, seventy-eight widows (5.3 per cent) extended credit for a total of 32,628 livres (7.4 per cent), while in the seigneurie of Florimont forty-four ( 7.07 per cent) lent out money for a total of 25,125 livres ( 8.2 per cent). Some of these women extended credit several times throughout the period. During the eighteenth century, the participation of widows in the credit market was quite irregular, with the exception of the seigneurie of Florimont in which they gradually came to participate more in terms of number and volume. It is worth noting that their loans were on average no smaller than those of men.

Where did the loans made by widows go? Who were widows' clients? Just like unmarried women, securing their capital was certainly the main preoccupation of widow investors. Indeed, widows first lent to men (almost 50 per cent in Delle and 60 per cent in Florimont in terms of volume) and to married couples (55 per cent in Delle and 35 per cent in Florimont in terms of volume). In terms of risk-taking, widows, like other female creditors, took minimal risks and tightly secured their transactions. Protecting their capital for their old age appears logical. Laurence Fontaine suggests that widows were very active in proximity lending. ${ }^{48}$ This pattern is similar to what we have observed among unmarried women. Capital extended to their neighbours was high, but no higher than any other category.

\section{Credit Activities and Female Empowerment}

As unmarried women and widows invested their money in the credit market of their local communities, we might ask whether they benefitted in any way from these activities. Were these women empowered? And if so, how? Can we measure empowerment? But first, let us sketch the contours of 'pre-industrial empowerment' and outline the framework in which women could find freedom of action.

\section{Characteristics of Early Modern Empowerment}

Modern microcredit activities are often associated with the notion of empowerment and emancipation. Countless studies have asked whether or not microfinance does empower women. Despite this scholarly and political interest, there is no clear consensus among scholars about what modern empowerment is supposed to encompass and entitle. Empowerment can be roughly defined as the power or

48 Fontaine, L'économie morale, p. 159. 
the ability to influence decision making. ${ }^{49}$ It could also be a process of becoming more influential within one's household or/and community. Jo Rowlands also argues that empowerment includes the process that leads people to perceive themselves as able and entitled to make decision. ${ }^{50}$

If we consider the sphere of microcredit, for example, women are supposed to gain financial independence, assertiveness, respect, and autonomy both within their household and within their communities. Ultimately, these female beneficiaries of microcredit are also supposed to contribute to economic development. This definition remains a bit blurry and the means to achieve empowerment is often vague. This has lead Serene Khader to note that, 'though donor agencies and academics routinely describe empowerment as a development goal, there is little agreement of what type of life changes constitute empowerment and why such changes are ultimately valuable'. ${ }^{51}$

Early modern or pre-industrial empowerment was, in essence, not intrinsically different. The term 'empowerment', and the concept itself, were of course not used or referred to by contemporaries. I believe that the notion of 'pre-industrial empowerment' implied a transformative dimension, a change in the distribution or application of power. It was an improvement of one's situation, a challenge in a certain power dynamic. A person or a group, an institution, or a situation, could empower a group or an individual. The process itself could take place in practice without necessarily being formally identified by the agents as such, i.e. as empowering. What differed from our contemporary society was perhaps the way early modern society was organized and structured. When we consider women in the early modern period, we refer to a group of individuals who traditionally had less power, influence, authority, and economic and political opportunities than men. Across Europe, not only did countless institutions, organizations and markets legally bar access and deny rights to female members, but pre-industrial consciousness and norms validated this de facto biological sex order and, therefore, discrimination. As a result, pre-industrial female empowerment was deeply connected with the challenge of patriarchy. ${ }^{52}$

For the purpose of this article, I tentatively sketch a framework assessing the empowerment of early modern female creditors. How can we assess the

49 On empowerment see especially Bacqué and Biewener, L'empowerment; Duflo, 'Women, Empowerment'; Pitt and others, Does Micro-Credit Empower Women?

50 Cited in Parpart and others, 'Rethinking (Em)powerment', p. 11.

51 Khader, Adaptive Preferences, p. 173.

52 On this see especially Dermineur, 'Anatomy of Early Modern Patriarchy'. 
economic and social effects of lending activities? What are the factors we need to look at? It is difficult, for obvious reasons, to assess the social impact of credit activities, above all for the early modern period. Points of comparison, at this stage, are still greatly missing. What follows is an attempt to bring some key elements to the debate. In order to do so, marital status is once again a useful tool of analysis.

\section{Single Women and Autonomy}

As previously explained, single women creditors did play a dynamic role in the local economy, increasingly extending more capital throughout the eighteenth century. If their participation in the local credit market corresponds to an increasing economic need for liquidity and funds, we can nonetheless suppose that these women benefitted from their lending activities. I believe that the involvement of more single women in the credit market corresponded to a community need, rather than to an active involvement on women's part in financial activities. ${ }^{53}$ Single women had increasingly greater access to cash because of their service-oriented labour and their savings capacity (most of these female servants were rural servants, and benefitted from room and board, amplifying their saving capacity). The service-oriented labour market expanded in the eighteenth century. These female domestics represented, therefore, potential creditors. We can argue that their participation in the credit market was sought out; especially in an economy where cash remained scarce.

We might ask what kind of social benefits these single women lenders obtained. Rosenthal observes that 'quantitative analysis of credit activity suggests that individuals used these markets to invest their savings and withdrew their funds when they needed to provide for their children'; in the case of single women, it is likely they withdrew their money in order to get married, demonstrating a certain independence from their families, opportunities in the labour market, and an appreciation for investment and protection of their assets. ${ }^{54}$ Marie Margueritte Beuné is a good example. She lent 512 livres in May 1745 to three different creditors, thus diversifying her investment. In November 1747, she married Antoine Betevy

53 In northern Sweden and in Finland, Tiina Hemminki has shown that the first savings banks' main clients were in fact female domestics. Her dissertation is in Finnish, the English title is 'Wealth, Credit, and Trust: The Lending Relationships of Peasants on Both Sides of the Gulf of Bothnia 1796-1830'.

54 Rosenthal, 'Rural Credit Markets and Aggregate Shocks', p. 305. 
and could count on her returns from the credit market to increase her dowry and her new household's capital..$^{55}$ Her assets were thus protected and returned a small profit into the bargain. Thanks to their wages invested in the credit market, female domestics showed independence and assertiveness.

These women, who invested their savings and domestic wages in the credit market, might have been able to relieve their parents of part, or perhaps all, of their endowment at marriage. Several marriage contracts in the area mentioned cash in the dowry provision. ${ }^{56}$ We still lack data on this critical issue and can only hypothesise. If we consider the inheritance system - partible in this region - and if we suppose that some brides were able to provide for their own dowry, then we might reconsider the traditional pattern of inheritance. Indeed, in regions of partible inheritance historians have asserted that, in practice, daughters were often excluded from their parent's inheritance after they had been endowed at marriage, while their brothers would be endowed and receive their share of the family property at the deaths of their parents, creating an inheritance practice that was highly discriminatory and based solely on gender. ${ }^{57}$ In the case that some women were able to provide their dowries themselves, there was no obstacle to them accessing their parent's property and inheriting the same share as their brothers. While this is an interesting hypothesis, more data and research could help to verify it.

A second hypothesis could also be developed. We might suggest that these single women had more freedom to choose their life partner thanks to their ability to negotiate loan contracts, their access to resources and their possible dowry provision. To date, historians know very little about the choice of marriage partner in traditional communities. This issue would also need more data and research but could prove to be significant.

\section{Widows and Promised Independence}

I have shown elsewhere that women in general, and widows in particular, did benefit from a change in legal norms in the second half of the eighteenth century, and this related to their involvement in the credit market. ${ }^{58}$ This is very clear in marriage contracts. Indeed, an increasing proportion of marriage contracts allocated the

\footnotetext{
55 ADTB 2E4/ 157.

56 Dermineur, 'Women in Rural Society', Chapter 3.

57 See especially Derouet, 'Le Partage des Frères'.

58 Dermineur, 'Widows' Political Strategies in Traditional Communities'.
} 
surviving spouse - in most cases the widow - a greater share of the couple's estate and greater protection. This development became particularly visible after 1760 . In the seigneurie of Delle and Florimont, we see that the provisions stated in these contracts became increasingly favourable to women, and especially to widows. ${ }^{59}$ The division of community property, which traditionally entitled a widow to a third of the community property in this region, was increasingly modified by the soon to be wed couples, granting half to each spouse. ${ }^{60} \mathrm{It}$ is worth noting that, in the majority of cases, the surviving spouse was in fact the wife. ${ }^{61}$ Therefore, the increasing protection afforded to the surviving partner did intentionally protect widows.

Additionally, other new legal provisions were progressively introduced in these marriage contracts, which further protected widows. The provision of the survivor's benefits embraced a broad range of possibilities, usually deliberated upon and negotiated by the contracting parties themselves. ${ }^{62}$ Among the types of insurance available for the surviving spouse, we find the following: the dower, a discretionary provision which could be unilateral, usually in favour of the widow; mutual donation, which was egalitarian regardless of sex; provisions in case there were children and in case there were none; usufruct, unilateral or mutual; and a possible combination of several of these features, along with other gifts that did not respond to clear legal norms but rather to specific familial situations. All these changes, I argue, were directly related to the increasing participation of women in credit activities. Protecting the widow's assets and patrimony was beneficial to her household, her social capital, but also to creditors.

One reason for the legal improvement of the condition of widows could lie, paradoxically, in the difficult economic situation that was emerging in the eighteenth century, and in the greater involvement of women in the credit market. First, the equal share of the community property, and the adoption of new legal measures protecting widows, could be a direct consequence of economic change. Indebtedness, indeed, grew substantially in the eighteenth century, especially in its second

59 About this specific region see especially Bouvalot, Coutumes de la Haute-Alsace; Storti, 'Coutume de Ferrette et/ou coutume du comté de Belfort'.

${ }^{60}$ In my sample, this new provision was progressively applied in the 1720 s and gradually came to be used by the majority of betrothed couples; in the 1760s it was at 53.13 per cent and it continued to grow until finally it came to dominate the marriage contracts of the 1780s at 81.4 per cent.

61 For figures see Maillard, 'Les Veuves Dans La Société Rurale'.

62 As many studies have by now shown, the surviving spouse was in most cases the woman. See for example, Maillard, 'Les Veuves Dans La Société Rurale'. 
half. ${ }^{63}$ In this particular region, like elsewhere in early modern France, peasants increasingly borrowed more money and had difficulty in meeting their repayment deadlines. Many of them, then, proceeded to associate their wives to the loan, in order to bring greater, and new, guarantees to the deeds and to reassure creditors; as a consequence, wives then became accountable for half of the debt. As a husband and a wife borrowed money together, the loan was secured through their borrowing capacity as a couple, that is, through the property held in common, and through the lineage property of each (including women's dowries). ${ }^{64}$ Leaving the widow half of the community property could potentially discharge the heirs of a greater debt, and above all made the wife fully responsible and accountable for her actions, transforming her into a joint economic partner, while reassuring potential creditors and business partners. ${ }^{65}$

This informal legal evolution did not originate directly in the involvement of widows in the credit market but, rather, in the involvement of women in general in the extension of credit. Moreover, the strategies adopted by peasants to secure the position and status of widows did not originate from widows alone, but were most probably the result of a consensus reached in the community, derived from other complex social and economic strategies employed by peasants in order to cope with external economic effects, such as growing indebtedness. As previously stated, widows' capital could benefit the active population greatly in a system of capital redistribution.

The association of women with the economic viability of the household and farm did force a crack in the traditional paradigm of patriarchy, allowing for the survival of the family and of the lignée. Everyone in the community contributed to combatting the effects of indebtedness, and to the search for, and creation, of capital. Women, regardless of their marital status, became associated with this process, more by necessity than by will. Wives were increasingly associated with their husbands in the search for capital in the credit market, thus becoming key economic partners. Widows were similarly solicited to extend credit, just as single women did. ${ }^{66}$ Everyone in the community participated in the effort to ensure its survival

63 See among others Fontaine, L'économie morale; Grenier, L'Economie d'Ancien Régime. And for this particular area see especially Boehler, Une Société; Dermineur, 'Female Peasants, Patriarchy'.

${ }^{64}$ Dermineur, 'Women in Rural Society'.

${ }^{65}$ More on this here: Dermineur, 'Les Femmes et Le Crédit'; Dermineur 'Trust, Norms of Cooperation, and the Rural Credit Market'.

66 See especially Dermineur, 'Single Women'. 
and to cope with indebtedness. Such a consensus is not surprising, as norms of cooperation and reciprocity were high in traditional communities. ${ }^{67}$

Both the enhancement of access to resources for widows and their participation in the credit market improved their living conditions and certainly contributed to their empowerment both socially and economically. Measuring and evaluating empowerment proves to be extremely difficult, but we can observe the effects of these changes for widows here and there in other documents. For instance, it appears that widows did serve progressively more often as guarantors to back loans in the credit market, indicating the social credit they benefitted from. ${ }^{68} \mathrm{We}$ also see that, towards the end of the eighteenth century, widows were more numerous in negotiating the marriage contracts of their children. About 24 per cent of brides had their marriages arranged solely by their widowed mother. Alyson Poska has found similar figures in early modern Galicia. ${ }^{69}$ Widows who negotiated the marriages of their children played a key role in the negotiation process and their authority was asserted more or less with force, depending on how successful they were. Widows similarly appeared less often before judges in the last decades of the eighteenth century, perhaps indicating that their status and greater access to resources preserved them from conflict. ${ }^{70}$

These are the indications of some of the changes affecting women in general. We need to be extremely careful in arguing that these new conditions were in fact an effect of female empowerment resulting from women's increasing key role in credit activities. Causation, effect, and correlation can easily be intermingled. Future studies on this topic will help us to clarify the social effects of female participation in credit markets.

\section{Conclusion}

Thanks to their credit activities, female creditors benefitted from some social improvement in their status. In a common assumption, the female sex and marital

67 See Dermineur, 'Trust, Norms of Cooperation, and the Rural Credit Market'.

68 Dermineur, 'Women in Rural Society'.

69 Poska, Women and Authority, p. 119: 'In my examination of approximatively 300 marriage and dowry contracts in the province of Ourense, only about one-third of the brides had two living parents at the signing of the marriage contracts'. 'More than $28 \%$ of brides had their marriages arranged and/or dowries arranged solely by their widowed mothers'.

70 Dermineur, 'Women in Rural Society'. 
status constituted a fundamental barrier to independence, emancipation, privileges, and social prerogatives, especially in pre-industrial rural communities. But, thanks to women's involvement in the credit market and their lending activities, women fulfilled a key social function, rewarded in turn by greater social freedom, especially regarding marriage, an important stage in life not only for women but also for their families. First, investing their wages and savings in the credit market might allow these women to relieve their families of part — or all — of the dowry. By doing so, perhaps single women could, in turn, freely choose their future spouse. More work remains to be done in this area to back up this idea. Widows who extended credit could also enjoy greater social credit and a more recognized position as heads of their households. Finally, the activities and gradual presence of women in the credit market also had an important impact on the social fabric and the interaction of women with their families and towards men. To some extent, a proportion of these women were necessary actors in the credit market, a social and public sphere in which, in a traditional assumption, they were not expected to interact. As this study has shown, women could be empowered by credit activities. I believe, however, that a number of factors needed to come together in order for empowerment to crystallize in practice.

More research on this topic will shed more light on these critical issues. In particular, the cross-examination of notarized loans and informal loans may reveal more about women's role and activities in rural credit markets.

\section{Works Cited}

\section{Manuscripts}

Archives Départementales du Territoire de Belfort, 2E 4/155-59, 2E 4/194, 2E 4/222-23, 2E 4/245-46, 2E 4/257-58, 2E4/279-80

\section{Primary Sources}

Bouvalot, Edouard, Coutumes de la Haute-Alsace dites de Ferrette (Colmar: Barth et HeldBaltzinger, 1870)

\section{Secondary Studies}

Banerjee, Abhijit V., and Esther Duflo, Poor Economics: A Radical Rethinking of the Way to Fight Global Poverty (New York: Public Affairs, 2011)

Bacqué, Marie-Hélène, and Carole Biewener, L'Empowerment, une Pratique Emancipatrice (Paris: La Découverte, 2013) 
Beauvalet-Boutouyrie, Scarlett, Etre Veuve Sous l'Ancien Régime (Paris: Belin, 2001) Bhatt, Nitin, and Shui-Yan Tang, 'Making Microcredit Work in the United States: Social, Financial, and Administrative Dimensions', Economic Development Quarterly, 15.3 (2001), 229-41

Boehler, Jean-Michel, Une Société Rurale en Milieu Rhénan: la Paysannerie de la Plaine d'Alsace (1648-1789) (Strasbourg: Presses Universitaires de Strasbourg, 1995)

Briggs, Chris, 'Empowered or Marginalized? Rural Women and Credit in Later Thirteenthand Fourteenth-Century England', Continuity and Change, 19.1 (2004), 13-43

Dermineur, Elise M., 'Anatomy of Early Modern Patriarchy', in Revisiting Gender in European History, 1400-1800, ed. by Elise M. Dermineur and others (New York: Routledge, 2018), pp. 10-28

— , 'Female Peasants, Patriarchy, and the Credit Market in Eighteenth-Century France', Proceedings of the Western Society for French History, 37 (2009), 61-84

_ ' 'Les Femmes et Le Crédit Dans Les Communautés Rurales Au 18e Siècle', Traverse Revue d'Histoire - Zeitschrift Für Geschichte, 2 (2014), 53-64

— 'Single Women and the Rural Credit Market in Eighteenth-Century France', Journal of Social History, 48.1 (2014), 175-99

— , 'Trust, Norms of Cooperation, and the Rural Credit Market in Eighteenth-Century France', Journal of Interdisciplinary History, 45.4 (2015), 485-506

—, 'Widows' Political Strategies in Traditional Communities: Negotiating Marital Status and Authority in 18th c France', in Gender and Political Culture, 1500-1800, ed. by James Daybell and Svante Norrhem (Farnham: Routledge, 2016), pp. 123-39

-, 'Women in Rural Society: Peasants, Patriarchy and the Local Economy in Northeast France, 1650-1789', unpublished PhD dissertation, Purdue University, 2011

Derouet, Bernard, 'Le Partage des Frères. Héritage Masculin et Reproduction Sociale en Franche-Comté aux XviIIe et XIXe Siècles', Annales. Économies, Sociétés, Civilisations, 48.2 (1993), 453-74

Duflo, Esther, 'Women, Empowerment and Economic Development', Journal of Economic Literature, 50.4 (2012), 1051-79

Duflo, Esther, and others, 'The Miracle of Microfinance? Evidence from a Randomized Evaluation'. Working Paper. National Bureau of Economic Research, May 2013. <https://doi.org/10.3386/w18950>

Fontaine, Laurence, Pauvreté, Crédit et confiance dans l'Europe préindustrielle (Paris: Gallimard, 2008)

Froide, Amy M., Never Married: Singlewomen in Early Modern England (Oxford: Oxford University Press, 2005)

Grenier, Jean-Yves, L'Economie d'Ancien Régime: Un Monde de L'échange et de L'incertitude (Paris: Albin Michel, 1996)

Hanawalt, Barbara A., The Ties That Bound: Peasant Families in Medieval England (Oxford: Oxford University Press, 1989)

Hardwick, Julie, 'Seeking Separations: Gender, Marriages, and Household Economies in Early Modern France', French Historical Studies, 21.1 (1998), 157-80 
—_, 'Widowhood and Patriarchy in Seventeenth Century France', Journal of Social History, 26.1 (1992), 133-48

Hemminki, Tiina, 'Wealth, Credit, and Trust: The Lending Relationships of Peasants on Both Sides of the Gulf of Bothnia 1796-1830', unpublished PhD dissertation (in Finnish), University of Jyväskylä, Finland, 2014

Hoffman, Philip T., and others, 'Information and Economic History: How the Credit Market in Old Regime Paris Forces Us to Rethink the Transition to Capitalism', The American Historical Review, 104.1 (1999), 69-94

- Priceless Markets: The Political Economy of Credit in Paris 1660-1870 (Chicago: University of Chicago Press, 2001)

_- 'Redistribution and Long-Term Private Debt in Paris, 1660-1726', The Journal of Economic History, 55.2 (1995), 256-84

Holderness, B. A., 'Widows in Pre-Industrial Society: An Essay upon their Economic Functions', in Land, Kinship and Life-Cycle, ed. by Richard M. Smith (Cambridge: Cambridge University Press, 1984), pp. 423-42

Jordan, William Chester, Women and Credit in Pre-Industrial and Developing Societies (Philadelphia: University of Pennsylvania Press, 1993)

—., 'Women and Credit in the Middle Ages: Problems and Directions', Journal of Economic History, 4 (1988), 33-62

Khader, Serene, Adaptive Preferences and Women's Empowerment (New York: Oxford University Press, 2011)

Laurence, Anne, and others, eds, Women and their Money, 1700-1950: Essays on Women and Finance (London: Routledge, 2008)

Lemire, Beverly, and others, eds, Women and Credit: Researching the Past, Refiguring the Future (Oxford: Berg, 2001)

Lindgren, Håkan, 'The Modernization of Swedish Credit Markets: Evidence from Probate Records', The Journal of Economic History, 62.3 (2002), 810-32

Maillard, Brigitte, 'Les Veuves Dans La Société Rurale au XvinIe Siècle', Annales de Bretagne et Des Pays de l'Ouest, 106.1 (1999), 211-30

Ogilvie, Sheilagh, A Bitter Living: Women, Markets, and Social Capital in Early Modern Germany (Oxford: Oxford University Press, 2003)

Parpart, Jane L., and others, 'Rethinking (Em)powerment, Gender and Development: An Introduction', in Rethinking Empowerment: Gender and Development in a Global/Local World, ed. by Janes L. Parpart (London: Routledge, 2002), pp. 3-21

Pitt, Mark, and others, Does Micro-Credit Empower Women? Evidence from Bangladesh (Washington: World Bank, 2003)

Poska, Allyson M., Women and Authority in Early Modern Spain: The Peasants of Galicia (Oxford: Oxford University Press, 2006)

Rosenhaft, Eve, 'Did Women Invent Life Insurance? Widows and the Demand for Financial Services in Eighteenth-Century Germany', in Family Welfare: Gender, Property and Inheritance since the Seventeenth Century, ed. by David Grenn (London: Praeger, 2004), pp. 163-94 
Rosenthal, Jean-Laurent, 'Rural Credit Markets and Aggregate Shocks: The Experience of Nuits St. Georges, 1756-1776', The Journal of Economic History, 54.2 (1994), 288-306

Sabean, David W., Property, Production, and Family in Neckarhausen, 1700-1870 (Cambridge: Cambridge University Press, 1991)

Spicksley, Judith M., "'Fly with a Duck in thy Mouth": Single Women as Sources of Credit in Seventeenth-Century England', Social History, 32.2 (2007), 187-207

Storti, Marie-Lyse, 'Coutume de Ferrette et/ou coutume du comté de Belfort', Revue d'Alsace, 132 (2006), 205-44

Wahid, Abu, 'The Grameen Bank and Women in Bangladesh', Challenge, 42.5 (1999), 94-101

Wrightson, Keith, and others, Poverty and Piety in an English Village: Terling, 1525-1700 (Oxford: Oxford University Press, 1995) 